\title{
Autonomy in HIV testing: a call for a rethink of personal autonomy in the HIV response in sub-Saharan Africa
}

\author{
Kasoka Kasoka ${ }^{1}$ (D)
}

Published online: 13 June 2020

(c) Springer Nature B.V. 2020

\begin{abstract}
The author reviews various conceptions of autonomy to show that humans are actually not autonomous, strictly speaking. He argues for a need to rethink the personal autonomy approaches to HIV testing in sub-Saharan Africa (SSA) countries. HIV/AIDS has remained a leading cause of disease burden in SSA. It is important to bring this disease burden under control, especially given the availability of current effective antiretroviral regimens in low- and middle-income countries. In most SSA countries the ethic or value of personal autonomy or self-determination is promoted as primary in HIV testing decisionmaking. SSA policymakers have an ontological and moral duty to adopt HIV testing policies that reflect human and medical realities, relationships, local contexts, and respect human rights for both individuals and others who are affected by HIV in society. Without rethinking the value of autonomy in HIV testing decision-making, the article cautions that attainment of the Sustainable Development Goal (SDG) 3 and the UNAIDS fast-track strategy that explicitly call to end the epidemic by 2030 will not be feasible for SSA.
\end{abstract}

Keywords AIDS $\cdot$ Common good $\cdot \mathrm{HIV}$ response $\cdot$ Personal autonomy $\cdot$ Rethinking autonomy $\cdot$ Sub-saharan africa

\section{Introduction}

The case of COVID-19 pandemic has more than ever presented to the world that individual autonomy in society is at best conditional and relational. The coronavirus intrusive measures taken to contain the virus expose the fundamental problem in metaphysics - the issue of what makes a person the same over a period of time-and the moral dilemma posed in bioethics by the fact that an individual who lives in society with others is promoted as a sovereign of her own body, medical choices and life.

This dilemma might otherwise be expressed: "what makes a person the selfsame person today as who he or she was yesterday' (Ndete 2016), and what does autonomy mean to an individual whose exercise of self-governance has inescapable ramifications on the wellbeing and rights of others. Thus, should there be a need to rethink the personal

Kasoka Kasoka

Kasoka_k@protonmail.com

1 School of Law, Birkbeck, University of London, London, UK autonomy ${ }^{1}$ premising of informed consent requirements in HIV testing in most sub-Saharan African (SSA) countries, since informed consent requirements in HIV testing are mainly premised on personal autonomy? (Beauchamp and Childress 1979/2000; Fraser 2005; United Nations 2009; Naidoo and Vernillo 2012). Or there isn't a need to rethink because humans are, as Kantian and related notions of autonomy tell us, normatively and narratively sovereign selves? In this article I seek to show that personal autonomy, strictly speaking, is an illusion, and its primacy in healthcare ethics is morally problematic.

In most of SSA countries the HIV prevalence has stabilised at high rates. The SSA region carries a disproportionate HIV burden, accounting for $70 \%$ of the worldwide burden of infection (Bulstra et al. 2020). HIV/AIDS is a leading cause of morbidity and mortality in the region (Dwyer-Lindgren,

\footnotetext{
1 Throughout this paper, the term "autonomy" will variously refer to the capacity or ability to self-govern, including moral independence (Gaylin and Jenkins 2003). According to Smebye et al. (2016, p. 1), 'autonomy has a range of different meanings such as "self-rule, selfdetermination, freedom of will, dignity, integrity, individuality, independence, responsibility and self- knowledge"... Autonomy is also identified with the qualities of intentional actions and being free from controlling influences'.
} 
et al. 2019). ${ }^{2}$ This is despite that major scientific breakthroughs (availability of effective HIV therapy) that have shifted the HIV paradigm that was once was considered a death sentence are now mostly available in the region. Even with the availability of HIV medication in SSA countries like Zambia, AIDS still remains the most common cause of death. ${ }^{3}$ And yet, individual citizens are still celebrated and told through HIV laws or policies that they have a right to refuse HIV testing because they are sovereigns of their own health, life and destiny (Castell v. De Greef 1994; Southern Africa Litigation Centre 2012). Therefore, does this temptation and pursuit to view ourselves as autonomous HIV testing decision-makers blind us to an observable reality that shows that as humans we are interdependent and inextricably social and socialised beings?

Three decades into the HIV epidemic, HIV still poses a real health challenge from which no country in the world is immune, particularly SSA countries. According to UNAIDS' factsheet, at the end of 201937.9 million people worldwide were living with HIV (UNAIDS 2020a, b, c). The same source indicates that 74.9 million people as of the end of 2018 became infected with HIV since the beginning of the epidemic. Of the 74.9 million infected, 32 million have since died from AIDS-related illnesses. This makes HIV/ AIDS one of the major causes of morbidity and mortality in the world. HIV/AIDS is the second leading cause of death in SSA (Business Insider 2017).

Given the threat of the epidemic, it is not surprising that all the United Nations member states agreed to reach certain targets in response to the disease (Suthar et al. 2013). These targets were set to be achieved by 2015. Some of the targets included the reduction of sexual and parental transmission of HIV by $50 \%$, elimination of vertical HIV transmission, reduction of TB deaths among people living with HIV by $50 \%$, and delivery of ART to 15 million people (Suthar et al. 2013; Udjo and Lalthapersad-Pillay 2015). It was noted that the achievement of such goals requires that people test for HIV since it is only through knowledge of one's serostatus that one can be linked to prevention, treatment and care services (Suthar et al. 2013).

It is encouraging to note that such efforts have led to significant degrees of progress in response to HIV. Overall, HIV infections are approximated to have been reduced by $40 \%$ between 2000 and 2013, with 13.6 million people globally reported to have been receiving ART as of June 2014 (United Nations 2015). At present, new worldwide efforts are being made to end the epidemic by 2030. On 8 June 2016

\footnotetext{
${ }^{2}$ Out of the estimated 6000 new HIV infections which happen daily worldwide, two out of three of these HIV infections happen in subSaharan Africa (Kharsany and Karim 2016, p. 34).

${ }^{3}$ According to UNAIDS (2020a, b, c), 78\% of people worldwide who knew their HIV status were as of 2018 accessting ART, and among those accessing ART, $86 \%$ were virally suppressed.
}

United Nations General Assembly (UNGA) member states adopted, also in the light of the 2030 Agenda for Sustainable Development and other, a new political declaration that seeks to end AIDS by 2030 (UN General Assembly 2016; UN News Centre 2016). The declaration includes a set of time-bound targets to fast-track response to reach three identified milestones by this year (2020). The 2020 milestones being: reduction of new HIV infections globally to less than 500,000 ; ensure that $90 \%$ of people infected with HIV know their HIV status, $90 \%$ of people who know their status are on put on ART, and $90 \%$ of those on ART have suppressed viral load (UNAIDS 2015, 2016; UN News Centre 2016). ${ }^{4}$

According to UNAIDS, scale-up of ART has put the reach of the global commitment to end HIV by 2030 on track (UNAIDS 2016). Moreover, Kharsany and Karim state that the substantial declines in HIV infections are the result of HIV testing scale-up and widespread coverage of ART (Kharsany and Karim 2016, p. 35). Thus, it is apparent that the above UNGA targets can only be achieved if there is an increased uptake of HIV testing and counselling (HTC), and increased access to HIV prevention and care services (Suthar et al. 2013, p. 23). Recognising the critical importance of HIV testing, indeed one of UNAIDS' 90-90-90 2020 targets is that $90 \%$ of of all persons living HIV will know their HIV status (UNAIDS 2020a, b, c). As of 2018, 79\% of all PLHIV knew their HIV status (UNAIDS 2020a, b, c).

The importance of HIV testing uptake cannot be overemphasised. Its advantages include: being able to initiate early treatment for those who test positive at the time their immune system is still strong; early diagnosis improves long-term survival rates; knowledge of one's HIV status helps in prevention of HIV transmission to one's sexual partners, foetuses, babies, caregivers and other; knowledge of one's HIV status prevents re-infections, and; a positive test even for those who have been diagnosed later means one can still have access to life-saving treatment (St Maarten AIDS Foundation 2003).

Put differently, 'an HIV test opens the door to accesing a range of HIV prevention options available depending on a person's HIV status to keep themselves and their loved ones HIV-negative' (UNAIDS n.d.). HIV testing is indeed critical as an entry point for HIV treatment and care. ${ }^{5}$ UNAIDS

\footnotetext{
${ }^{4}$ One of the principles of the Fast-Track approach also calls for change; that is, among other things, stopping what does not work when it comes to the HIV response 'and scaling-up proven programmes' (UNAIDS 2015, p. 6).

5 'HIV testing services (HTS) are the entry point for diagnosis and access to life-saving antiretroviral therapy (ART). Early diagnosis and initiation of ART have been shown to drastically decrease viral load, which reduces individual morbidity and mortality, and limits onward HIV transmission. HTS can also offer a pathway for primary prevention interventions, including programs that deliver pre-exposure prophylaxis, voluntary medical male circumcision, and prevention of mother-to-child transmission' (al., 2019).
} 
and WHO have confirmed that adherence to an effective ART regimen can result in reduction (by 96\%) of the risk of transmitting the virus to an uninfected sexual partner, and can cause viral suppression that will lead to a PLHIV living a normal lifestyle and longer life expectancy. Without ART, PLHIV develop AIDS as a result of a compromised immune system, thereby exposing them to development of infections, certain cancers, and other severe clinical manifestations (UNAIDS 2016; UN-DESA 2017).

In this vein, I am in favour of programmes such as the 'WHO Test and Treat' policy in SSA. Those countries in SSA which have already adopted and implemented this approach are therefore to be commended. The introduction of 'test and treat' programmes have significantly contributed to an increase in the number of people accessing treatment (Skovdal et al. 2016; Avert, 2019a, b; UNAIDS, 2020a, b, c). SSA governments can alocate money, including requesting for HIV programmes funding from international donors, purchase mobile clinics and hire testing community workers to go door-to-door in communities and educate people about HIV prevention and the importance of HIV testing to an individual and common good, and then offer counselling and on-the-spot HIV testing and ART initiation whenever individuals consent (EGPAF 2017; Sulat et al. 2018; Silberner 2019). This should be done in combination with routine HIV testing in healthcare facilities.

Without further delay, before the preparation of this article, I was aware that issues surrounding personal autonomy in HIV testing are multifaceted - therefore they cannot be all explored in this article. Thus, the scope of this article is limited. Firstly I have not explored various cultural conceptions of autonomy in this article (for such see the position of, Mbiti 1970; Gaylin and Jennings 2003; Woods 2002-2004; Traphagan 2013; Song 2018) who have suggested that the primacy of the value of autonomy has its roots in Western liberalism (particularly American). I have only mentioned in passing the SSA traditional ontological outlook and its potential impact on HIV healthcare ethics. Secondly, the scope of the present review does not include a review of issues surrounding autonomy in clinical practice, including whether it is even possible to actualise informed consent requirements in medical practice (for this see, the position of Manson and O'Neill 2007).

Thirdly, I have not explored in detail issues surrounding personal autonomy, HIV stigma and discrimination, and hence, some may argue, the importance of personal autonomy in healthcare practice. I am persuaded that the subject area of stigma versus personal autonomy deserves a critical exploratory article of its own. Nonetheless, I have written this article having bourne in mind existing study findings and reports on stigma and discrimination (April 2009; Stangl and Grossman 2013), ${ }^{6}$ which, by implication, indicate that humans are social beings affected by the social environment.

Extensive studies that have found that fear for HIV stigma compromise HIV testing uptake and/or ART adherence are also arguably an indictment on how respect to personal autonomy in HIV healthcare should be viewed. If indeed humans are self-rulers and rational players, why should social stigma prevent them from making self-rational and moral decisions in directing their own HIV medical therapy for their own good, and direct their lives as they deem fit? Why should patients be declared and imputed with personal autonomy and yet at the same time blame the impact of social stigma on preventing potential HIV service-users from seeking medical attention? Is this not conceptually and practically conflicting?

And lastly, this paper does not explore whether the approach to HIV testing and treatment should be different from how we approach cancer, malaria, tuberculosis, COVID-19, etc., even in light of HIV treatment universal health coverage. For my positions on this, I agree with HIV exceptionalism conclusions that criticise the subjectivism tendency to separate HIV response approaches from broader health systems (De Cock and Johnson 1998; April 2009; Oppenheimer and Bayer 2009; Smith and Whiteside 2010; Benton 2015). I agree that HIV exceptionalism was necessary before access to and effective ART was made available in SSA.

Indeed, the HIV exceptionalism force is losing its original power as HIV has become less threatening (Smith and Whiteside 2010) due to accessible and effective HIV medication-treatment which has now been made available for the majority of affected populations in SSA. 'Through the combined efforts of people living with HIV, national public health programmes, global donors and a broad community

\footnotetext{
${ }^{6}$ Basing autonomy on guarding against stigma can be problematic. Among other things, April (2009) arguing for opt-out HIV testing versus the issue of stigma noted: 'Under an opt-in programme, .... [a person] remains oblivious of her infection and avoids any immediate repercussions from her community. Yet, this only delays the consequences - she will inevitably progress to AIDS. In societies with high HIV prevalence, as in much of sub-Saharan Africa, it is all but certain that her community will find out the cause of her suffering. It will be precisely at the time of her greatest physical ailing and need for emotional support that she will suffer the burden of HIV stigma and discrimination. In the case of an opt-out programme, although her decision to test may not have been borne of her own initiative, her decision not to decline testing will empower her to control the circumstances of her disclosure and formulate a plan for addressing her disease'.
} 
of stakeholders, the number of people on antiretroviral therapy (ART) rose rapidly across SSA, going from about 100,000 in 2004 to 15.4 million by the end of 2017' (Nash et al. 2018, p. 1). ${ }^{7}$

Hence, almost all countries in SSA have adopted HIV national policies to treat all persons, regardless of CD4 cell count (SSA has an HIV prevalence of 25.7 million people) (Nash et al. 2018). The massive expansion of ART treatment in SSA has continued to save millions of lives, hence a need to even advance more appropriate HIV testing ethics. The scope of this article therefore concerns itself with a review whether a person who can test for HIV and have access to ART is an autonomous patient who should be encouraged to choose her own medical therepy for her own good. The chief aim of this article is to show by reviewing procedural, substantive, ontological and socio-relational autonomy theories that capacity or achievement of autonomy in human society is an illusion, strictly speaking. Thus, premising informed consent requirements of HIV testing testing on personal autonomy is problematic, philosophically and ethically. I have demonstrated that since humans don't exist in a vacuum, but are born into society and live in families and communities with fellow human beings, the promotion of primacy of personal autonomy over the common $\operatorname{good}^{8}$ is inappropriate.

The value of autonomy has been recognised as the core of medical ethics and has been validated by court judgments as a primary good in a free society (Faden and Beauchamp 1986; Planned Parenthood v. Casey 1992; Airedale NHS Trust v. Bland 1993; C v Minister of Correctional Services 1996; Lewanika v. Frederick Chiluba 1998; Huri - Laws v. Nigeria 2000; Diau v Botswana Building Society 2003; Southern Africa Litigation Centre 2012). For example, emphasising its primacy, the South African High Court even held that '[i]t is, in principle, wholly irrelevant that [the patient's] attitude is, in the eyes of the entire medical profession, grossly unreasonable, because her rights of bodily integrity and autonomous moral agency entitle her to refuse medical treatment' (Castell v. De Greef 1994).

\footnotetext{
7 In East and Southern Africa, $67 \%$ of adults and $62 \%$ of children living with HIV are on ART (Avert 2019a, b).

${ }^{8}$ In this article, I have used the word 'common good' to mean 'the sum of those conditions of social life which allow social groups and their individual members relatively thorough and ready access to their own fulfillment' (Velasquez et al. 2014). The " "common good" refers to those facilities - whether material, cultural or institutional-that' individual 'members of a community provide to all members in order to fulfill a relational obligation they all have to care for certain interests that they have in common' (Hussain 2018). And as John Finnis held, 'respect for human rights is a requirement of justice and that "the maintenance of human rights is a fundamental component of the common good"' (Finnis 1980, cited in Hussain 2018).
}

Compounding this, the worldwide media through television dramas and documentaries foster this perception that individual choices or wishes are/ought to be sovereign in medical decision-making (English et al. 2006). The individual or health service-user's medical judgment is celebrated as a right to be make one's own decisions for one's own health, body and life (Southern Africa Litigation Centre 2012). The individual is held to be a master of her own body and destiny, and is free to resist any violations to her autonomy (Diau v. Botswana Building Society 2003) against others of whom she lives with in society.

Behind the promoted freedom, autonomy, choice, and personal rights now stands a particular vision of what is entailed in being a human being; social relationships and arrangements are only recognised as far as they are able to nurture the atomistic self (Gaylin 1996). And behind this vocabulary of a sovereign human being is the belief that human behaviour is voluntarily chosen, and that other people's conduct can be modified through rational argument (Gaylin 1996; Gaylin and Jennings 2003). The case of the COVID-19 crisis shows otherwise. ${ }^{9}$ My article interrogates the personal autonomy arguments and reaches a conclusion that the philosophy surrounding the value is problematic, as well as, it is silent on the ethics of the actual implications of an autonomous decision in HIV testing (Selemogo 2010).

This article is, therefore, composed of three themed sections. It begins by giving a brief overview of the origin of the word 'autonomy' and its evolution, and its relationship to informed consent in healthcare ethics. The second section analyses the various conceptions of autonomy. Thirdly, an alternative conception of autonomy is reviewed and advanced (a review of whether autonomy is social as opposed to individual). The paper concludes by referencing the implication of a social view of autonomy on HIV testing in SSA where HIV is an epidemic. Jones (2020) more

\footnotetext{
${ }^{9}$ In discussing the impact of the coronavirus crisis, Tobias Jones observes: 'It has been fascinating to see the speed at which other attitudes have changed. The indignation expressed towards people not respecting social distancing (from those who would never normally describe themselves as moralists) has been understandably shrill: here too we've suddenly realised that the wellbeing of the group is endangered by indifferent individuals, and that community - for which we've yearned for so long - means originally simply a pooling of duties.... [T] he philosopher and activist Simone Weil wrote that "the notion of obligations comes before that of rights. It's a complicated, but convincing case, and it seems to me that in the last month there has been a radical shift in the balance between rights and responsibilities that has changed the timbre of our lives. I've never seen so many news items about applause, or so many social media posts accompanied by clappy emojis. Before, "in the absence of adversity", the psychiatrist and philosopher Iain McGilchrist said this month: "We grew flabby, selfish. We manufactured grievances that now can be seen for what they were." Now, when people meet their obligations to us we're obliged' (Jones 2020).
} 
recently argued that what the coronavirus public health responses worldwide have shown us is that 'wellbeing isn't individual but social', and that humans 'are not actually independent at all'.

\section{The origin of autonomy, its relationship with informed consent, and HIV testing in SSA}

Jackson (2013) explains that the word autonomy is from the Greek words autos (self) and nomos (rule), which originally was used to refer to cities' independent self-rule. ${ }^{10}$ Feinberg (1986), among others, also have noted that the word has a Greek origin which comes from the Greek for 'self' and 'law', meaning the making of one's own laws. In tracing the roots of personal autonomy, Taylor (2005) suggests that individual self-authorship has its roots in the Romantic liberalism of John Stuart Mill (2015), in which free development of individuality was promoted. Feinberg (1986) states that personal autonomy has interrelated meanings, from one's capacity to govern oneself, to the sovereign authority to govern oneself.

O'Neill (2003) provides that the original view of autonomy in antiquity - meaning self-legislation-never referred to persons, but to property. That is, ancient autonomous citystates made their own laws, colonies being given laws by the colonising parent cities (O'Neill 2003, p. 3). So, unlike its original cities' self-rule application, autonomy has now been extended to indicate the self-governance of rational independent individuals.

This extension to an autonomous human has been adopted in medical ethics, and universalised, incuding in SSA. Patient autonomy is promoted through informed consent requirements.

Informed consent has become one of the fundamental principles in medical ethics and law (Dhai 2008). Individuals are held to have inviolable bodily and psychological integrity. This body-mind integrity right is violated when a patient is afforded medical intervention: without informing her in a language she understands the nature of the therapy; she has not been told about associated benefits and risks; available options in respect to an intervention have not been disclosed, and; she has not been informed that she has a right to refuse (McQuoid-Mason 2008). Unlawful medical

\footnotetext{
$\overline{10}$ Gaylin and Jennings (2003, p. 28) explain that autonomy means "the state of being self-governed or self-sovereign" - living autonomously means living by a law that you impose on yourself. "The autonomous individual freely acts in accordance with self-chosen plan' (Gaylin and Jennings 2003).
}

interventions that do not respect patient autonomy can constitute assault at law (Dove et al. 2017).

In common law, free and informed consent means an inclusive recognition and respect of a: patient's capacity (and competence) to consent; disclosure of information to a patient related to the nature and extent of risks incident to a medical intervention; patient understands risks involved; patient is informed about available medical options, and; patient voluntariliy consents to (or to refuse) a medical intervention (Beyleveld and Brownsword 2007; McQuoidMason 2008). Put differently, the legal and ethical elements of informed consent are: capacity; disclosure; understanding, and; voluntariness (Dhai 2008). A healthcare professional who by commission or omission fails to respect these requirements may be held responsible for any injury resulting therefrom. In this vein, " $[\mathrm{t}] \mathrm{he}$ traditional Hippocratic belief that one could do almost anything on a patient as long as the principles of beneficence (best interests) and nonmaleficence (no harm) were upheld has been considerably' stamped by rational and moral individuals whose autonomous actions or choices take precedence (Dhai 2008, p. 27).

The principle of informed consent in clinical practice is primarily a negative right of non-interference (Schermer 2002; Clarke 2009). '[I]t is closely connected to a particularly Western, post-Enlightenment idea that an adult person is a bounded individual who is able to live her life freely in accordance with her self-chosen plan, and ideally independently from controlling influences' (Dove et al. 2017, p. 150). Its underpinnings can be traced to the influential Kantian and Millan conceptions of autonomy-or humans as rational self-legislators who are ends in themselves (Selemogo 2010). Thus, 'in the domain of Western biomedicine, the epitome of personal autonomy is a patient expressing a decision that she has come to autonomously and independently' (Dove et al. 2017, p. 150).

To this effect, potential HIV service-users are told that they have the right to "make choices that meet with their own interests according to their own will... [because humans have] capacity to understand substantial information, form a judgment according to their own values and communicate with the physician freely about their wishes' (Song 2018, p. 296).

In this article, I have not questioned the importance of informed consent in healthcare conduct, and in HIV testing in particular. What I question is the premising of informed consent requirements on personal autonomy. I hold that grounding informed consent on autonomy distracts attention from observable human reality-which is that there are various important aspects of and factors in life that obstruct and pose challenges to realisation of personal autonomy in society. Thus, instead of promoting personal autonomy, I advance a promotion of greater cooperation between patient, healthcare professional and one'a family and community. 
Beauchamp and Childress' definition of an autonomous patient who has freedom from controlling influences is mistaken.

\section{Autonomy does not lie in satisfying a psychological feature of the brain or mind}

Different schools of thought have advanced various conceptions of what autonomy means. O'Neill (2003) has enumerated such definitions: dignity, integrity, individuality, independence, responsibility and self-knowledge; liberty; self-assertion; knowledge of one's interests; freedom from obligations; absence of external causation; choosing one's own moral position and accepting responsibility for one's own choices; self-mastery, voluntariness; privacy; and choosing freely.

In the following review, much reference has therefore been made to Killmister's (2013) thoughts on autonomy because the author identifies critical aspects of autonomy that have been overlooked in various theses by celebrated luminaries. Killmister's structure and analysis of the subject matter is instructive for the present review. Hence, the current analysis will be restricted to a critical review of feminist accounts; Kantian accounts of autonomy which have been embraced by a number of feminist thinkers will therefore be reviewed.

Although feminists reject Kantian and Rawlsian notions of autonomy due to the former's argument that autonomy is relational, there are still different theses within the feminist school of thought which are arguably similar to Kantian conceptions - the only major difference being that such feminist scholars advance a relational account of autonomy due to their rejection of self-sufficiency of human beings. Besides Marina Oshana's socio-relational theory being arguably a more persuasive feminist account of autonomy, other accounts arguably embrace Kantian and Rawlsian rational choice theories.

\section{Procedural accounts of autonomy}

I commence by considering the reflective or historic endorsement accounts of Frankfurt (1988), Dworkin (1988) and Christman (2009). The theses of these great thinkers indicate that an individual's capacity for autonomy lies in her psychological dispositions. Nonetheless, Christman's reflective endorsement theory has been credited as an account that is placed to address the problem of socialisation-it is argued that his theory overcomes the inadequacies identified in procedural models such as those of Dworkin (1988) and Frankfurt (Killmister 2013). In fact, Christman has argued that Gerald Dworkin and Harry Frankfurt's first and second-order desire theories overlook the autonomycompromising nature of manipulation.

Being autonomous, according to Dworkin and Frankfurt, is synonymous with a capacity to critically evaluate firstorder values, desires and preferences by referencing them to one's second-order preferences, values, and desires. Thus, one's capacity 'to accept or attempt to change these in light of higher-order preferences and values' makes one autonomous (Dworkin 1988, p. 20). ${ }^{11}$ It is held that by exercising such a capacity under second-order desires, persons define their nature, give meaning and coherence to their lives, and take responsibility for the kind of person they are (Dworkin 1988 , p. 20). Under this theory, second-order values ought to take priority over first-order ones; second-order values are considered to be an individual's realm of autonomous decision-making.

I wish to argue that Dworkin and Frankfurt's second-order accounts are philosophically and, consequently, morally problematic. Philosophically, this rational thesis of autonomy fails to convincingly account for the problem of socialisation of values, desires and preferences, internalisations of which compromise second-order values. A person's socalled second-order desires can be a product of socialisation. Effective manipulation can reach all the way to second-order desires. Thus, indeed 'to judge as autonomous individuals who are hypnotized, brain-washed, or otherwise manipulated into developing second-order desires... is to misunderstand the very nature of autonomy' (Killmister 2013, p. 98). Holton has illustrated: 'to see this [philosophical problem of second-order thesis], suppose that I implanted a second order desire in you by hypnosis... then surely you wouldn't have free will if you got your desires to conform to that; but Frankfurt's account seems to have the consequence that you would' (Holton 2003, p. 2).

\footnotetext{
11 'A first order desire is a desire for anything other than a desire; a second order desire is a desire for a desire. So, for instance, you might have a first order desire to smoke a cigarette; and a second order desire that you desire not to smoke a cigarette... Thus [another example], I might wish that I wanted to give all money to charity, since I might think that having such a desire would show me to be an excellent person; but I might nonetheless not actually want that desire to be effective... But when a person does want the first order desire to be effective, when they want it to be their will, Frankfurt calls this a second order volition' (Holton 2003, p. 1). It can be inferred from this thesis that a person can act autonomously through identification with second-order desires. That is, a person is seen to have autonomy in so far as she has second order volitions and can bring her first order desires into line with second order volitions or desires. Thus, according to this account, dogs and children don't have autonomy because they lack second-order desires or volitions (Holton 2003). They don't have autonomous second-order desires which can be used to control first-order desires. First order values can, for example, be values which form the edifice of a given moral system. Thus, common good morality can be situated in first-order values (Ockham's Beard 2010).
} 
Frankfurtian and Dworkinian accounts possess a great potential to declare someone who is acting on internalised values to be autonomous. Such accounts seem to neglect the fact that external conditions (in the form of, e.g., societal rewards and punishments, and limiting human biological factors) have a tendency to make humans conform to certain behaviours (Gaylin and Jennings 2003). This can be seen in the present case of coronavirus where, due to fear of receiving fines or fear of being viewed as social deviant, among other reasons, people who would otherwise wish to open their entertainment venues, go to clubs, restaurants, bars and other social facilities, or go on holidays cannot now do so. Internalised first-order desires have consequences on second-order desires. Internalised ideas, fears, and values which we later mistakenly come to identify as our own have inescapable consequences on our daily choices or preferences (Lanier and Henry 2010). ${ }^{12}$

A good example of internalised preference can be inferred from the 18-year-old student theorised by Benson (1991). Benson explores the case of an 18-year-old whom through internationalisation of the Hollywood idea that appearance is a criterion of self-worth ends up regarding beauty and fashion as essential for her self-worth. First and second-order autonomy accounts fail to explain away this lived social reality.

Although it is possible to hold individuals to have acted autonomously by virtue of fulfilling Frankfurtian or Dworkinian first and second-order requirements, it can also be argued that morally this thesis of autonomy may be amoral because it has the potential to ignore that well-being can only be achieved when both individuals and others in society act responsibly towards each other. The common good values which sustain and advance the well-being of society can be denigrated through such outlooks, and the consequences of this would be the annihilation of millions of human beings and the end of human civilisation as we know it, as each individual acts according to their own second-order values.

What about Christman's theory of autonomy which Killmister claims is more persuasive? Does Christman, who criticises Frankfurtian theories of autonomy, provide a more realistic perspective? According to Christman's view, for an individual to claim autonomy 'necessary endorsement must

\footnotetext{
12 'One of the more astonishing features of current political debates on autonomy and coercion is the naïve underlying assumption about rationality and human motivation. Psychology - whether based on behaviourism or on its diametric opposite and antagonist, Freudianism (or any of the splinter of these two dominant branches) - views few pieces of human conduct as rational choices selected at the moment. Rather, modern motivational psychology tends to see most human behaviour as being "conditioned" or "unconsciously determined," a consequence or product of life experiences that tend to make responses to certain stimuli automatic and unchosen...' (Gaylin and Jennings 2003, pp. 16-17).
}

be directed at the process of desire-formation, rather than the desire itself' (Christman 2009; Killmister 2013, p. 98). Christman's theory of autonomy to me is equally an internalist or rational theory of autonomy.

Stoljar explains:

For Christman, preferences or desires will be nonautonomous only if they fail either a competence condition or a hypothetical reflection condition. Competency corresponds to the capacity of the agent to form effective intentions relative to a desire as well as to reflect critically about the desire. The hypothetical reflection condition employs the notion of non-alienation to characterize authenticity and hence autonomy. (Stoljar 2014, p. 235).

Killmister has illustrated and differentiated Christman's account from other procedural accounts of autonomy as follows:

For instance, we can take an individual who desires to eat a slice of cheesecake. Rather than asking, as Dworkin and Frankfurt would, whether the individual desires to desire to eat a slice of cheesecake, Christman asks how she would feel about her desire, were she to be aware of how the desire were formed. If the desire were implanted by a hypnotist, and knowledge of this process caused the individual to feel alienated from the desire, then that desire [according to Christman] would not be autonomous. (Killmister 2013, p. 98).

For Christman, for an action to be autonomous the individual must personally identify with the desire through a feeling of non-alienation. Like Frankfurtian and Dworkinian visions of autonomy, I wish to argue that Christman's endorsement account is unpersuasive. Endorsement accounts of autonomy fail to account for internalisation of norms, values which an individual may mistakenly endorse or identify to be her own. Indeed, the problem with Christman's theory is not the 'inclusion of a historical version of reflective endorsement..., but rather that this condition is insufficient to determine the autonomy of an individual' (Killmister, 2013 p. 100).

Christman's hypothetical reflection account fails to appreciate that due to deeply ingrained traditional values, imparted through oppressive (and I add non-oppressive) ideological socialisation over many years of one's life, individuals can identify with deformed desires and not feel alienated (Stoljar 2014). Effects of ideological socialisation and environmental changes can cause one to treat stereotypes and acquired feelings as natural to oneself and thus formulate one's desires and plans based on such ingrained nonautonomous desires (Gaylin and Jennings 2003). Recipients of socialised ideologies 'are unlikely to experience alienation from either the 
norms that they have internalized or the preferences formed on the basis of the norms' (Stoljar 2014, p. 235).

\section{Historical account of autonomy}

Mele's (1995) external historical account is a hypothetical counter-example to procedural accounts (Killmister 2013). Mele dismisses psychological (internalistic) accounts of autonomy (Christman 1999) as insufficient. He advances that, if all individual human beings were like Athena or a god, procedural accounts of autonomy would indeed capture what amounts to autonomy, and therefore his (Mele's) historical account of autonomy would be unnecessary. However, because humans are not Athenas, he argues that his alternative account is therefore valid or convincing and necessary (Mele 1995). I actually find Mele's account of autonomy more persuasive than Frankfurt, Dworkin and Christman's accounts put together.

For Mele, for an agent to be autonomous her actions must not be compelled by another:

It is a historical property of agents required for responsibility for the possession of a pro-attitude. A necessary condition of an agent $S$ 's authentically possessing a pro-attitude $\mathrm{P}$ (e.g., a value or preference) that he has over an interval $t$ is that it be false that S's having $\mathrm{P}$ over that interval is, as I will say, compelled - where compulsion is not arranged by S. (Mele 1995, p. 166).

The implication of Mele's theory is that pro-attitudes can violate an individual's autonomy. To this effect, Mele's theory implies that second-order desires (explained above) must not be a product of pro-attitudes or compulsion. He predicates his theory on an understanding that humans are susceptible to acting on socialised values (compelled or instilled pro-attitudes ${ }^{13}$ ). According to Mele, compelled pro-attitudes, therefore, make individuals non-autonomous (Mele 1995).

Put differently, an agent's choices are nonautonomous, according to Mele's exposition, when:

an agent comes to have a pro-attitude because of an external force, rather than via exercise of her skills for critical reflection and evaluative judgment; (ii) the instilled pro-attitude is one she is unable (in the absence of radical counterfactuals) to eradicate or attenuate; (iii) she did not arrange the by-passing herself; and (iv) she does not, nor did she earlier, possess

\footnotetext{
13 A pro-attitude is a person's mental attitude (a feeling or opinion about someone or something) directed toward an action under a certain description; pro-attitudes may include moral views, desires, urges, aesthetic principles and economic prejudices (Bunnin and $\mathrm{Yu}$ 2004).
}

other pro-attitudes that would support her endorsing the instilled pro-attitude. (Killmister 2013, p. 101)

The implication of this understanding of autonomy is that human motivation is susceptible to socialised pro-attitudes that are difficult to efface. Mele's exposition of autonomy makes more sense as it touches on external factors that internalist accounts of autonomy fail to account for. Indeed, a fully competent individual who is able or capable of acting rationally upon desires (values which she has critically reflected upon) cannot necessarily by this very token be safely considered autonomous, as the pro-attitudes (which she considers to be her own) could have been socialised earlier in life.

However, I do not completely agree with Mele's thesis regarding what he then advances as constituting autonomy. This disagreement lies in Mele's advancement of an alternative theory of self-control as being a mechanism through which one can achieve autonomy. This theory (capacity for autonomy by virtue of self-control) appears to water down the fact that both inculcated cognitive biases and environmental changes can compose the very mechanics of self-control. ${ }^{14}$

Mele's self-control theory does not satisfactorily explain how the problem of socialisation of pro-attitudes acquired since childhood can be qualified in the assessment of what amounts to one's autonomous self-control. Studies have established that babies do not have competent mental capacities for reflection during early childhood-a period when they acquire pro-attitudes. ${ }^{15}$ Killmister has argued that there is a problem in Mele's theory if it is to be used as a guide for identifying 'autonomy-inhibiting socialization' (Killmister 2013, p. 101). Mele's approach would rule out most early childhood education directed at developing the very necessary mental capacities. Killmister postulates that if the relevant capacities are inoperative or not yet developed, as they will be in very young children, Mele takes them to have been bypassed' (Killmister 2013, p. 70).

\footnotetext{
${ }^{14}$ Despite an individual being perfectly able to appraise critically and act upon her desires and values, the perfectly self-controlled person may nevertheless be acting on desires and values that have been implanted into her by artificial means, ones whose development has bypassed normal reflection and awareness' (Christman 1999, p. 96).

15 'Human beings are born biologically premature, so that unlike most mammals, many of our neurological and physical functions and all of our behavioral capacities exist at birth in potential form only. To come to fruition, these potentials must be molded by a social environment' (Gaylin and Jennings 2003, p. 34). The conditions which influence our everyday adult conduct are set by our parents and culture early in life through a conflation of coercion, parental encouragement, emotional intimidation, conditioning, and other mechanisms (Gaylin and Jennings 2003).
} 
Mele has nonetheless acknowledged that bypassing is common in infants but argues that such bypassing is not sufficient for compulsion unless the pro-attitude is also practically non-sheddable. To this, Killmister has responded that many people have pro-attitudes (traceable to early childhood socialisation) that they are practically unable to shed. She claims that even our attitudes towards evidence, reason, and reflection are both presumably inculcated and nearly unsheddable:

The problem here is that one of the central roles of socialisation is to inculcate the very pro-attitudes that are required for the kind of self-control Mele sees as necessary for autonomy. To be self-controlled is to believe and desire on the basis of an assessment of evidence. This will rely upon having the appropriate pro-attitudes towards evidence and reasons, which must at some point have been instilled in the child. (Killmister 2013, p. 102).

Also, Tomis Kapitan observed:

In our early development each of us is subjected to physical and social forces of which we are largely ignorant, over which we have no control, yet from which we acquire values, beliefs, motivations, and capacities for rational evaluation that subsequently guide our choices and actions. These forces "destroyed" any capacity to become a different sort of person with selfcontrol regarding any unsheddable pro-attitude that we happen to have. Consequently, every unsheddable proattitude is compelled, and anyone with firm unshakeable principles of action ends up being inauthentic and non-autonomous. (Kapitan 2000, p. 89).

\section{Substantive accounts of autonomy}

Stoljar rejects procedural approaches to autonomy by replacing them with a substantive account (Stoljar 2000, 2014). She argues that procedural conceptions fail to appreciate that people who have been subjected to false and oppressive internalised norms cannot be autonomous. According to her thesis, oppressive socialisation can lead an individual to internalise false beliefs which the victim may later come to endorse as her own. Decisions made on the basis of internalised false beliefs are therefore not autonomous, she declares.

Stoljar's thesis indicates that mere possession of false/ oppressive beliefs makes an individual non-autonomous. I wish to agree with Killmister's observation that Stoljar's theory is initially promising as it acknowledges that 'the question for all theories is what kinds of socialisation are incompatible with autonomy' (Killmister 2013, p. 104). I, however, find Stoljar's account unpersuasive.
What is problematic about Stoljar's theory is that it reduces autonomy to an individual who is free from false/ oppressive socialisation (Killmister 2013). Such a perspective fails to consider that for an individual to be autonomous she does not only necessarily need to choose her own moral position but also enjoys the absence of any form of external influences on her self-determination capacity. That an autonomous individual is a self-ruler, or a law unto herself, no matter what form of socialisation she underwent, should not be ignored. An autonomous individual freely acts in accordance with a self-chosen plan by virtue of self-law and/ or morality (Kant 1785; Gaylin and Jennings 2003).

What the preceding arguments entail is that even nonoppressive internalised norms can still be non-autonomous, provided they were instilled or regulated by another or something external to the individual claiming autonomy. If to be autonomous is to be self-governing or self-directing or, in other words, to act on motives, values, and reasons that are one's own, then how can we restrict non-autonomous action to only false/oppressive socialisation? Moreover, the fact that the person who is supposed to be a law unto herself is at the mercy of false/oppressive socialisation shows a lack of sovereignty, like that of the Christian God, hence the illusion of autonomy.

\section{Dialogical accounts of autonomy}

The dialogical theses by Westlund (2009) and Benson (2011) view a person to be a social self. According to these accounts, a person's answerability to others becomes the key condition for autonomy. In other words, autonomy is synonymous with a person's ability to have normative power or authority over one's decisions (Mackenzie 2008). Autonomy thus becomes dispositional.

What is encouraging about dialogical approaches is that they indicate that human beings are interconnected-in other words, social selves. As will be shown below, however, the thesis of dispositional autonomy is unconvincing because this theory propounds that a capacity for autonomy is premised on an individual's mental capacity.

Westlund argues that autonomy should not be understood in terms of an individual's psychology or history; rather it is constituted by a particular kind of disposition. Her theory suggests that an agent's answerability to others is a key condition for autonomy. She rejects psychological accounts which designate an autonomous agent as one who critically reflects in an appropriate way in evaluating one's preferences, desires and motives. In other words, Westlund rejects rational choice accounts of autonomy because such theories merely argue that autonomy is achieved when an individual engages in critical reflection or if an individual acts or chooses to act in accordance with desires which she 
has self-reflectively endorsed (Friedman 2003; Christman 2009).

According to Westlund, one's autonomy is instead undermined if one is unable to give reasons in defence for one's actions or choices (Westlund 2009; Killmister 2013). So, an individual who readily answers for herself constitutes a self-governor or autonomous person, she suggests. According to Benson, an autonomous act is achieved when a selfregarding attitude is expressed in one's willingness to take responsibility for one's actions (Benson 2011). In this case, if an agent claims authority over her own actions, then such an agent can be considered autonomous.

These accounts suggest that certain emotional states and attitudes towards oneself are necessary conditions for autonomy. Such approaches appear to require that reliance on critical reflection and judgment for autonomy is only possible if a person can endure criticism of her own sense of basic competence and worth.

I wish to state that dialogical accounts of autonomy are philosophically and morally problematic. They are philosophically unpersuasive because such approaches ground autonomy on a person's ability to offer reasons for her choices. And these accounts are morally problematic because they are individualistic in outlook-such outlooks appear to promote autonomy on the basis of meeting moral obligations to self. ${ }^{16}$

Although Westlund criticises psychological accounts of autonomy, I wish to argue that dialogical accounts of autonomy are equally psychological or internalist in substance. Thus, the criticisms of rational choice accounts of autonomy can to a larger degree equally be applied to dialogical ones; both approaches clearly ignore or brush aside the reality of socialisation and environmental conditioning. Kantian psychological or rational conceptions of autonomy often erroneously portray agents as causally and psychologically independent of environmental conditioning.

Westlund regards someone as non-autonomous if they defer to something or someone rather than providing their own reasons in choice-making; however, she appears to ignore the fact that defending a choice with plausible reasons is not necessarily synonymous with being its author, or authentically identifying or individually valuing a given choice. An agent can defend, for example, oppressive values, not because that is what the agent desires, but because it is required. External circumstances can cause an agent to embrace oppressive values and yet still be in a position to stand behind a given decision as their own.

\footnotetext{
16 The promotion of the common good is arguably denigrated and sacrificed on the altar of self. 'To respect each person's interests in living her life in accordance with her own conception of good' (Mackenzie 2008) propagates indifferent individualism.
}

Thus, being answerable to one's choices or behaviour does not make one autonomous, but potentially makes one accountable to socialised values which one's external environment through interpersonal and environmental conditions have imposed upon or inculcated into the agent who is claiming autonomy. A person can give a convincing or persuasive reasoned answer to something not because she necessarily has chosen the value and identifies with it, but because of environmental conditioning and limitations. An agent is capable of defending inculcated or internalised oppressive values through adaptive preference formation (Elster 2016). ${ }^{17}$

Expressed differently, the problem with Westlund and Benson's conception of autonomy is that individuals can stand behind decisions or actions which are paradigmatically non-autonomous. This is especially true seeing that it is widely accepted that 'we humans are very good at inventing post-facto explanations of our actions, even to ourselves' (Moll 2004, cited in Killmister 2013, p. 108).

\section{Are there degrees of autonomy? A response to Suzy Killmister}

Killmister (2013) concludes by suggesting that we do not have absolute autonomy, but 'degrees of autonomy'. I hesitantly agree! One agrees in a strict sense that 'degrees of autonomy' can be in the form of restricted autonomies in which individuals have been placed under laws where boundaries have been drawn on how far they can conduct themselves. One may as well call this 'permitted autonomy'. It is within the boundaries of laws (natural or positive), ethics, regulations and conventions where one can agree that 'degrees of autonomy' are apparently found.

Thus, yes, we humans have no absolute autonomy. For example, the current COVID-19 lockdown and social distancing rules indicate that human autonomy is not absolute. Being the law unto oneself is limited to what governments proclaim are boundaries within which individuals can be allowed to rule themselves. However, founding autonomy on limited or relative autonomy also crumbles when the whole picture of human motivations, in light of the ever-changing environment, is closely examined. Thus, can Killmister convincingly enumerate in what circumstances exactly an agent can enjoy this limited autonomy, circumstances which are excluded from the susceptibility to socialisation, internalisation, biological influences or environmental changes?

\footnotetext{
17 Adaptive preference formation stifles autonomy because individuals, through limited options available to them in society, have their preferences unconsciously altered (Colburn 2011; Elster 2016). 'Preferences formed through adaptation are characterised by covert influence (that is, explanations of which an agent herself is necessarily unaware), and covert influence undermines our autonomy because it undermines the extent to which an agent's preferences are ones that she has decided upon for herself' (Colburn 2011, p. 52).
} 
Gaylin (1996) has established that human motivation and behaviour is highly susceptible to environmental influences. Therefore, he argues that protagonists of autonomy are mistaken in believing that human behaviour is voluntary. Gaylin submits that present behaviour is moreover significantly determined by past treatment (Gaylin 1996). He suggests that human behaviour is less rational than we are willing to admit. He advances that our behaviours are influenced by our emotions, which are usually more effective than logical argument, and adds that shame, fear, guilt, greed and pride influence human behaviour.

The implication of this analysis is that a combination of societal morality (morality which can be internalised through effective socialisation), the institution of law in society which defines the boundaries of human behaviour, and human natural susceptibility to emotions (as drivers of decisions) makes the argument for capacity for individual autonomy, even in limited circumstances, problematic.

Discussing the stifling nature of our biological make-up on human decision-making, Morison (1984) has observed that besides historical influences human 'agency' is encumbered with genetic or environmental factors which subtly motivate our day-to-day choices. For Morison, much of our human behaviour is significantly influenced by events over which we as individual have little or no control. He quotes Melvin Konner's The Tangled Wing: Biological constraints on the human spirit $(1982)^{18}$ work as an extraordinary book which identifies, among others, the roles genes and the environment play towards behaviours and choice:

It requires only a little reflection to realise... that our choice is strictly limited to the possibilities displayed before our conscious in real time including those we can call up from memory or create by synthesizing bits and pieces of previous experience... Not nearly so clear is the degree to which the final choice is also so conditioned or "shaped" by genetic patterning or by previous experience of which we are no longer conscious. My hunch is that such influences are much more numerous than we imagine and that autonomy in any strict sense is an illusion. (Morison 1984, p. 46).

\section{Autonomy is a social phenomenon}

My review of autonomy so far agrees with feminist relational accounts to the extent that feminists generally highlight 'that agency cannot be separated from interdependence, since large swaths of our lives, especially during the formative

\footnotetext{
18 Konner has demonstrated that man's behaviour is influenced by nature and nurture (Konner 1982).
}

years, are spent dependent on others, and those relationships function to inform our preferences, our values, and our understanding of our selves' (Wenner 2020). Hence, I have contended above that autonomy cannot be conceptually explained without convincingly explaining away the impact of human social embeddedness and environmental change on human capacity for autonomy.

I have thus shown that feminists' relational account analyses are only insufficient to the degree that they theorise that humans can be autonomous by virtue of a psychological state of mind. In the following discourse, I will show that autonomy is a social phenomenon.

Crittenden (1993) has observed that critics of liberalism, and even some liberal theorists, have criticised the emphasis of autonomy by liberalists. Indeed, internalist conceptions of autonomy are not only conceptually unconvincing, but also, since they are associated with self-sufficiency, they exude 'the worst aspects of atomistic individualism, insulation, social isolation, and an indifference to society's values and interests' (Crittenden 1993). The fact that humans are born into society, are interdependent, co-exist, and therefore have to act in solidarity for the common good is almost ignored in rational theories. Humans in psychological theories of autonomy become laws and morality unto themselves.

Crittenden, like Gaylin, acknowledges that human beings by nature are interdependent and interconnected. Hence, he argues that a conception of autonomy which is premised on self-sufficiency does not represent a fulfilment of autonomy but its abandonment. He submits that autonomy has a social nature and explains that autonomy develops through sociality, and it also requires sociality for its exercise. Crittenden quotes Anthony Arblaster, who has noted that it is not normal or even desirable for a human to be self-sufficient (Arblaster 1984). He also invokes Jennifer Nedelsky, who submits that 'the perfectly autonomous man is thus the most perfectly isolated' (Nedelsky 1989).

For Crittenden, autonomy does not entail isolation from the presence of the influence of others or a necessary rejection of societal values, but the very concept of autonomy depends on these very factors. 'The social nature of autonomy appears to undergird a communitarian notion of the self as socially situated' (Crittenden 1993, p. 37). The author argues, among other reasons, that he believes autonomy is social because humans are not born with autonomy, but that autonomy requires psychosocial development. He also argues that 'autonomy is social because we can only be autonomous when we know we are acting autonomously; and we can only know that when we give an account to others of how we arrived at a decision or action' (Crittenden 1993, p. 38).

According to Crittenden, the only autonomous person is one who is able to remove herself from the social matrix. $\mathrm{He}$ argues that since no person is born autonomous; we may 
only be autonomous through socially distancing ourselves from the social matrix.

He suggests that self-autonomy, provided one was born and lives in society, is impossible:

Any kind of introspection or reflection must be done in and through language, and the language we use is itself a cultural or social inheritance. We do not create it, and in this sense also autonomy has a social side... To make our actions and judgments intelligible to ourselves, we not only translate them into language, but also form them through language. The only language we have available by and through which to think rationally and self-reflectively, is one based on cultural tradition... There is implicit in every language, as part of that cultural tradition, a system of norms and standards that determine proper use. (Crittenden 1993, p. 44).

I agree with Crittenden's theory of social autonomy, even though there are issues which arise from a further reading of his account which I do not necessarily agree with. When Crittenden suggests that an autonomous person is one who is able to distance oneself from the social matrix - a matrix which one earlier identified with-this perspective appears to suggest that an individual is capable of extricating herself from the social context, and from her genetic make-up. If Crittenden means that an individual can extricate herself from the environment (a reality which has made that person who she is), I argue that doing so is not possible in reality due to biological constraints, interdependence, common human frailty, and socialisation.

In other words, because all human beings have internalised pro-attitudes, it is impossible for them to disown or separate themselves from what they are personally disillusioned to believe are their own personal values and aspirations, if they later on choose to live by themselves. That is, even if a person later decides to live alone, like the asocial koala which only has social intercourse with other koalas during the breeding season, that person very likely already has embedded pro-attitudes which they will inadvertently carry with them, unless they were nursed by a koala as a baby and have since lived alone in the jungle.

\section{Externalist (socio-relational) account of autonomy}

Feminist theorist Marina Oshana grounds autonomy on a socio-relational premise. Oshana submits that autonomy is equivalent to self-governance (she states that the synonyms for self-governing are: 'free-standing', to be independent (self-sufficient), to be separate, and to be self-ruling and sovereign) (Oshana 1998). She rejects psychological conceptions of autonomy and advances an externalist account. She invokes both the internalist (psychological) and externalist (socio-relational) perspectives in her conceptualisation of what autonomy is.

Oshana submits that individual self-governance is in reality social. For Oshana, 'autonomy is a condition of persons constituted, in large part, by external, social relations people find themselves in (or in the absence of certain social relations)' (Oshana 1998, p. 81). In this sense Oshana's conception is to some extent similar to Crittenden's theory. However, unlike Crittenden, Oshana adds that manipulation, coercion, subjection to the dominant will of others, and also 'the internal phenomena native to the individual such as captivity to desires or physical impulses, psychological neuroses, or weakness of the will' compromise the capacity for autonomy (Oshana 1998, p. 83).

Oshana criticises Dworkinian, Frankfurtian and Christmanian accounts of autonomy as inadequate because these accounts are internalist. Indeed, as shown above, rational accounts of autonomy premise capacity for autonomy on the 'structural and/or historical character of a person's psychological states and dispositions, and on an agent's judgments about them' (Oshana 1998, p. 83).

For Oshana, an individual does not become non-autonomous merely by being born in an environment where one has no control, but one becomes non-autonomous by virtue of the effects of the conditions of a given environment. She maintains that choice does not guarantee autonomy. This is because a person who may be exercising what appears to be genuine choice may be compelled to do so by others, and endorsing such choices from within does not guarantee autonomous agency (Oshana 1998). In regards to the assumption that critical reflection in a procedurally independent fashion makes one's choice an autonomous one, Oshana argues that 'being able to engage in critical reflection, to take stock of oneself and to shape oneself on the basis of this evaluation, does not guarantee that whatever state of affairs ensues from this activity will be one of autonomy' because autonomy does not exclusively depend on circumstances descriptive of an individual's psychology (Oshana 1998, p. 89).

Oshana has therefore advanced four conditions necessary for autonomy: critical reflection, procedural independence, access to a range of relevant options, and the condition of social-relational properties. She argues that an individual cannot be autonomous if: (i) one cannot engage in critical reflection or objective appraisal of one's motives or actions, and the environment in which one's putative values develop; (ii) if she is, in fact, influenced or restricted by others in ways that constrain autonomy (such influences can be by way of manipulation or coercion); (iii) that autonomy becomes questionable when a person claims that their decision was autonomous in circumstances where they were lacking in 
access to an adequate range of options; and, (iv) an individual who is in society (having relations with others) does not limit herself to relations which enable her to pursue her goals in a context of social and psychological security (Oshana 1998). She submits that these four conditions for autonomy are not mutually exclusive; they must all be satisfied for an individual to claim autonomy.

For Oshana, her account of autonomy has three benefits: it recognises the human condition; it recognises the status of humans as moral agents; and, that a socio-relational account of autonomy 'can easily explain how persons might be selfgoverning even when manifesting external or communal virtues that might appear to reduce autonomy' (Oshana 1998, p. 98).

The socio-relational conception of autonomy is more convincing, philosophically and morally. It not only appreciates that humans are unique, but also recognises that humans are only able to exercise their uniqueness or the "self" ${ }^{19}$ in a socialised world encumbered by fear, emotions, the need for social validation, a changing environment, and the need to act responsibly in order to protect and promote the common good for mutual well-being and survival.

\section{Towards HIV testing ethics of embeddedness and togetherness}

Ravven (2013, pp. 336-411) has shown that mounting data from history of ethics and neuroscience demonstrate that a human being is in reality the 'I That Is We'. She states that neurobiological and other evidence have shown that the body-mind boundaries ethics celebrated as inviolable by Millan and Kantian ontological theses are mistaken. Ravven demonstrates that the dimension of the human self extend beyond the scope of the body-mind, and that human investment in others in the world is finally what ethics is all about, and should be acknowledged as such. We are made for togetherness. Throughout, her analysis, she convincingly demonstrates how locating the self as distributed beyond our skins and brains can provide a more plausible and appropropriate ethical and moral approach to HIV testing decisionmaking ethics. For Ravven, 'the scope of the self as a moral agent, of who is performing a given moral action, can be distributed beyond the individual to groups, and even extend

\footnotetext{
19 '[T]he self is where our identity resides. It is the medium through which our actions are guided and our world is perceived... This is clear even from the dictionary definitions of self: "the total, essential, or particular being of a person," or "the essential qualities distinguishing one person from another," or "one's consciousness of one's own being or identity; the ego." ... [However] The self is not a truly autonomous ego, it is an interactive entity defined not just in terms of differences from others but in relationship to them' (Gaylin and Jennings 2003, pp. 145-146).
}

at times to whole contexts'. This indicates that HIV testing decision-making is in reality complex.

Firstly, by citing the work of Clark (2009), Ravven has demonstrated that the self as we understand it is joined to society and is one with the world. This is in contrast to individualised informed consent requirements which advance a self self. According to Clark (2009), reported by Ravven, 'at least some aspects of human cognition... [are] realised by the ongoing work of the body and/or the extraorganismic environment,' so that the 'physical mechanisms of the mind... are not all in the head' or in other central nervous system.'

Ravven explains that our attraction to selfhood fails to account for an observable reality that demonstrates that as humans we are not 'locked-in' agents-as beings whose minds and physical abilities are fixed quantities apt (at best) for mere support and scaffolding by...[our] best tools and technologies.' Instead, 'our minds and bodies are essentially open to episodes of deep and transformative restructuring in which new equipment (both physical and 'mental') can become quite literally incorporated into the thinking and acting systems that we identify as our own minds and bodies.'

She emphasises and advances that humans do not only discover the world within their selves, but also discover themselves as parts of it. This entails that humans ought not to conceive themselves as the whole story of the whole, but as part of the story that makes the whole story complete. This outlook is similar to SSA ontological perspective that situate a human as 'a part of the organic whole' (Mbiti 1970; Menkiti 1984; Diop 1991; Tutu 1999; Nussbaum 2003; Woods 2002-2004; Molefe 2019). Therefore, an HIV testing regime that locates HIV as a shared reality will also adopt appropriate ethics and human rights that intergrate this reality. Current HIV testing ethics and human rights on decision-making in SSA have not reflected this human reality (Eba 2015).

Secondly, Ravven shows how a person is an 'I That Is We' by invoking co-consciousness empirical findings that have demonstrated that 'the self as a fully aware self-aware includes perspectives that were initially 'other': third person perspectives now taken in as one's own have relocated the self outside itself and in another'. She suggests that as humans we create a shared self-a self that is both mine and yours-when we unconsciously integrate our people's values and perspectives with our first person perspectives. She therefore concludes that humans are at best relational selves who discover the self through other's eyes with whom they have a shared reality, and a shared world. Ravven indicates that humans share an environment of inescapable embeddedness. Thus, ethicists, including HIV policymakers in SSA, should begin to acknowledge and accept that the self cannot exist in a social vacuum. 
The discovery that the self is not atomistic therefore 'heralds the end of the...cherished illusion... namely the illusory goal of independence, self-sufficiency, and free autonomy' promoted in HIV testing ethics which seek to disintegrate the self from her social embeddedness:

At any given time the self is constructed by a relation to another person. 'People have as many selves selves as they have significant others.' These selves emerge from the early relationships with parents, siblings, extended family members, and others who have an impact on one's life, and they profoundly affect motivation and emotions. Unconsciously perceived similarity triggers the relational patterns to take hold, without our conscious awareness or even the ability to control the process... The other and the relationships are necessary for the feeling of 'me' of this 'me'... Heinz Koht [a psychoanalyst]... held that it is through 'expanding its selfexperience to include the whole surround' that an infant comes to be able to (1) feel itself confirmed as a self, (2) pursue its ambitions, and (3) pursues its ideals. (Ravven 2013, pp. 369-370).

Thirdly, describing findings from neurobiological experiments, Ravven reports that research by Thomas Metzinger and Olaf Blanke have also demonstrated that the boundaries of the self transcends the boundaries of our bodies and minds:

We mistake the feeling of the self as our interior, a soul-thing, a solid bounded essence that is our true self that we alone know and disclose to the world. But that is a false picture. We are more like verbs than nouns; we make parts of the world feel like the self, and we fill our feeling with our engagemnets in the world. (Ravven 2013, p. 372).

Fourthly, Ravven turns to neurochemistry discoveries, like the one by Donald W Pfaff, that have also illustrated that the self transcends body-mind. And suggests that ethics should be grounded on relational autonomy:

Pfaff shows that the feeling of the self and where we draw the line between the self and other, self and the world, depend upon particular neurochemicals. These chemicals that produce the self-other divide, he says, are sometimes turned off, and when they are we experience others as if they were ourselves. The neurochemistry that produces the feeling of self as extending into others, he argues, underlies ethics. He says the chemicals that turn off the feeling of self-other boundary operate in fear and in love, in empathy and in aggression, and in other situations. These chemicals create a sense of shared experience and even of merger. Pfaff believes that this mechanism produces ethical action by creating empathetic responses to others. (Ravven, 2013, p. 373).

\section{Implications of the view of the self beyond itself to HIV testing approaches in SSA}

The dominant, individualistic understanding of autonomy that features in' bioethics and medical ethics underpin the idea that individuals are 'in their ideal form, independent, self-interested and rational gain-maximising decision-makers' (Dove et al. 2017, p. 150). My review of autonomy in this article demonstrates that such a view is erroneous as it does not convincingly account for both external and internal (influences of biology on decision-making) environmental factors. This individualistic conception of an autonomous patient is inconsistent with lived human life-it does not capture the breadth of lived human reality that shows the 'I That Is We'. Conceptions of autonomy, especially in clinical practice, 'should accommodate the fact that people are rarely, if ever, fully independent individuals' (Dove et al. 2017 , p. 151), hence, as an example, the challenge posed by HIV stigma to HIV testing uptake. As humans, we are social, cultural and biological beings whose decisions, including in healthcare, are shaped by a conflation of powerful social, cultural and biological forces that often times are beyond us (Konner 1982; Gaylin and Jennings 2003; Ravven 2013; Sapolsky 2017). This is the more reason why we need each other as humans: as opposed to atomising ourselves.

HIV testing ethics in SSA should be premised on the human reality of a self beyond itself, as this approach captures the physiological, biological, pyschological, sociological and cultural aspects of human condition; unlike the Kantian and Millan conceptions of personal autonomy which are largely abstract psychological ontologies. Instead of advancing abstract ethics of a self within self and unto self, SSA HIV policymakers have also something to learn from SSA traditional and moral analysis that view a person as 'a person through other persons' (Mbiti 1970; Menkiti 1984) — an outlook that was developed in the light of SSA's unique experiences and lived reality, besides ontological deliberations.

This SSA outlook is consistent with the conclusion of my analysis in this article that suggests that humans are incapable of being autonomous - they are social creatures who constantly, also unconsciously, simulate the values of their socio-cultural environments as their own. Drawing ethics that recognise and reflect environmental impacts, including of love, empathy, fear and hate, on individual decision-making, will therefore be a good starting point for reconfiguring individualised HIV testing informed consent requirements in SSA. 
HIV testing policymakers in Africa should cease ignoring the impact of the illusion of personal autonomy on our shared humanity. Rather, they should explore their own lived experiences and reality, review studies that indicate that as human we are part of the organic whole, explore potential ethics grounded on the recognition of social attachments as evidenced in sexual and parental love, and even in friendship, resist the illusion of autonomy, and advance realistic ethics where the individualised cold isolated person is restored to who she really is: a unique part of an organic whole.

'Parent love and especially motherly love, 'take the blurring of identity between two living beings to new heights,'... [ - ] the upshot of all this is that the various mechanisms that induce sexual and parental attachment can be harnessed and be recruited for all kinds of prosocial behaviours and attachments' (Ravven 2013, p. 375), as opposed to surrendering HIV testing ethics to the seduction of autonomy.

To this end, I wish to invite SSA HIV policymakers to consider basing HIV testing on altruism, or what Ravven (2013) terms, an ethic of: 'shared selves'-'a sefiness that loses the boundaries of the skin and is extended and distributed to others'. A self who is born into society, is interdependent, interrelated, and shares with others shared human frailty and vulnerability. Recognising this kind self can lead to an appropriate reconfiguration of HIV testing ethics. HIV testing ethics, in particular informed consent requirements that are now premised on personal autonomy, should reflect a human being who is unique and yet a creature of the inescapable inculcating environment that makes her the 'I That Is We'. According to SSA traditional and moral thought, 'I am because we are', and 'we are because I am'.

Ravven states:

Mounting data from neurosciences show that evil is rooted in the failure to see others as ourselves. In the case of genocides such as the Holocaust, it is a collective failure of society-wide proportions. The self-other boundary beyond the skin is of central importance to rethinking of ethics, to a deeper understanding of both good and evil. (Ravven 2013, p. 377)

\section{Conclusion}

Personal autonomy cannot provide a sufficient and persuasive starting point for bioethics (O'Neill 2002, 2003), in particular HIV testing decision-making. It is necessary for SSA countries to reconfigure their healthcare ethics and place them within the overall compass of human condition, and in the light of the setting of SSA's unique socio-economic and cultural background (Wood 2002-2004; Ravven 2013; Joseph et al. 2018). It is appropriate to get rid of abstract liberal and libertarian concepts of an autonomous patient and reconsider the observable and lived situation of the relationship between patients and their environments. The emphasis on primacy of patient autonomy distracts attention from important aspects of life and healthcare: 'wellbeing is social'. It is crucial to eradicate the man-made autonomy versus medical intervention crisis and move towards greater cooperation. HIV testing informed consent requirements should be premised on ethics of love, honesty, empathy, sympathy, friendship, togetherness and solidarity. Personal autonomy is an illusion.

A review of the universalised dominant Western liberal view of personal autonomy demonstrates that the general agreement that informed consent in HIV testing is required to respect personal autonomy 'and that autonomy is a basic ethical value, is more apparent than real' (Manson and O'Neill 2007, p. 17). Personal autonomy, strictly speaking, is an illusion. Human lived experience and reality show that our lives and decisions are encumbered by combined forces of socialisation, genetics and changing external environmental factors that make the idea of an ability or capacity for autonomy resemble a fantastic dream which, when we wake up, we realise was just a dream and not something achievable in a real, civilised and striving society.

In this vein, universalised ethics which continue to premise informed consent requirements in HIV testing on personal autonomy are inappropriate. Human beings are not asocial or atomistic that they can be a law unto themselves; they are individuals who are enmeshed in complex social realities of reciprocity, mutual obligations, and responsibilities for amicable co-existence, well-being and survival.

Moreover ' $\mathrm{h}$ ] uman behaviour is less 'voluntary' than libertarians and theorists of autonomy would have" us believe (Gaylin and Jennings 2003, pp. 7-8). As indicated in the analysis, "human behaviour is less rational than most of us would like to believe it is', in that 'fear, greed, shame, guilt, and pride fuel the machinery of' our decision-making and choices (Gaylin and Jennings 2003, pp. 7-8). It is these aspects which should also be acknowledged and reflected in HIV testing informed consent requirements in SSA.

Like what has been shown in the COVID-19 pandemic response, persons living in SSA countries should be made aware that as social beings and living in complex relations with others in society, they have a duty to test for HIV because HIV is an epidemic that affect the lives of both people living with HIV and others (especially, close family members). The HIV epidemic not only affects the person living with HIV, but causes suffering, and some instances even death, to family members and people in the community. 
HIV testing, like the involuntary COVID-19 lockdowns and social distancing, is a common good. In other words, the effects of AIDS are often corporately felt within the arena of the 'I That is We'-especially in the SSA setting where relational autonomy is articulated (Woods 2002-2004).

In conclusion, whenever we as humans are faced with the temptation to celebrate our 'individual autonomous right', we should pause, consider, and remember that we are because of the humanity of others: our birth came through others; our name was given to us by others; we have been educated by others; the respect we demand is given by others; the first bath we had was given to us by others when we were born; our last bath will be given by others; our funeral and potentially dignified burial will be organised and conducted by others; and everything we have owned will be inherited by others once we are dead. We are simply not autonomous as individuals; we are but interdependent and interconnected social creatures. Therefore, we should act in solidarity towards each other by formulating appropriate HIV testing ethics and encouraging people to test for HIV so those who need it can access appropriate therapy.

The COVID-19 crisis has taught us that 'wellbeing isn't individual but social' (Jones 2020). This indicates that SSA countries may not be able to achieve the Sustainable Development Goal (SDG) 3 (United Nations 2019), together with the UNAIDS' fast-track strategy that explicitly call to end the epidemic by 2030 (UNAIDS 2014), if HIV testing policies in SSA continue to ignore that humans are social beings (Gaylin and Jennings 2003) and 'wellbeing isn't individual but social' (Jones 2020). It is up to HIV policymakers in these countries to re-examine personal autonomy in HIV testing, and hopefully identify appropriate bioethics and human rights policies which are reflective of natural human condition and are suitable for the SSA socio-cultural setting and HIV epidemic reality.

Acknowledgements This paper was prepared thanks to study support from Birkbeck, University of London, UK during the author's PhD studies. The author is also grateful to Prof. Matthew Weait, Deputy Vice-Chancellor - University of Hertfordshire for his supervisory support during research on the subject matter examined in this article.

Author contributions Author fully acknowledged.

Funding None.

Data availability Not applicable.Code availability None.

\section{Compliance with ethical standards}

Conflict of interest The authors declared that they have no conflict of interest.

\section{References}

Airedale NHS Trust v. Bland. 19931 All E R 821.

April, M.D. 2009. Rethinking HIV Exceptionalism: The Ethics of OptOut HIV Testing in Sub-Saharan Africa. Bulletin of the World Health Organization 88: 703-708.

Arblaster, A. 1984. The Rise and Decline of Western of Western Liberalism. Oxford: Basil Blackwell.

Avert. 2019a. HIV AND AIDS IN EAST AND SOUTHERN AFRICA REGIONAL OVERVIEW [Online]. https://www.avert.org/ professionals/hiv-around-world/sub-saharan-africa/overview. Accessed 16 May 2019.

Avert. 2019b. WHO TEST \& TREAT POLICY AND CHANGE IN ART UPTAKE [Online]. https://www.avert.org/infographics/who-testtreat-policy-and-change-art-uptake. Accessed 19 May 2020.

Beauchamp, T.L., and Childress, J. F. 1979/2001. Principles of Biomedical Ethics, 5th ed. New York: Oxford University Press.

Benson, P. 1991. Autonomy and Opressed Socialisation. Social Theory and Practice 17 (3): 385-408.

Benson, P. 2011. Narrative Self-Understanding and Relational Autonomy: Comments on Mackenzie C. Poltera, J, 'Narrative Integration, Fragmented Selves, and Autonomy'. Symposia on Gender, Race and Philosophy 7:1-5.

Benton, A. 2015. HIV Exceptionalism: Development Through Disease in Sierra Leone. Minneapolis: University of Minnesota Press.

Bulstra, C.A., et al. 2020. Mapping and Characterising Areas with HIGH Levels of HIV Transmission in Sub-Saharan Africa: A Geospatial Analysis of National Survey Data. PLOS Medicine 17 (3): e1003042.

Bunnin, N., and J. Yu. 2004. The Blackwell Dictionary of Western Philosophy [Online]. https://www.blackwellreference.com/public/ tocnode?id=g9781405106795_chunk_g978140510679517_ss1271\#citation. Accessed Mar 2020.

Business Insider. 2017. HIV/AIDS is No Longer the Leading Cause of Death in Africa [Online]. https://www.businessinsider.com/ hivaids-is-no-longer-the-leading-cause-of-death-in-africa-2017$8 ? \mathrm{r}=\mathrm{US} \& \mathrm{IR}=\mathrm{T}$. Accessed 19 May 2020.

Castell v De Greef, 1994 (4) All SA 63 (CC) at 74 (S. Afr.).

C v. Minister of Correctional Services, 1996 (4) SA 292 (T) (S. Afr.).

Clarke, D.L. 2009. Moral Principlism Alone is Insufficient, and Traditional Moral Theories Remain Important for Practical Ethics. SAJBL 2 (2): 54-58.

Christman, J. 1999. Reviewed Work(s): Autonomous Agents: From Self-Control to Autonomy by Alfred R. Mele. The Journal of Philosophy 96 (2): 95-99.

Christman, J. 2009. The Politics of Person: Individual Autonomy and Social-Historical Selves. Cambridge: Cambridge University Press.

Colburn, B. 2011. Autonomy and Adaptive Preferences. Utilitas 23 (1): $52-71$.

Crittenden, J. 1993. The Social Nature of Autonomy. The Review of Politics 55 (1): 35-65.

De Cock, K.M., and A.M. Johnson. 1998. From exceptionalism to normalisation: A reappraisal of attitudes and practice around HIV testing. BMJ 24: 290-293.

Dhai, A. 2008. Informed consent. SAJBL 1 (1): 27-30.

Diau v Botswana Building Society (IC no 50/2003).

Diop, C.A. 1991. Civilisation or Barbarism: An Authetntic Anthropology. Brooklyn, NY: Lawrence Hill Books.

Dove, E.S., et al. 2017. Beyond Individualism: Is There a Place for Relational Autonomy in Clinical Practice and Research? Clinical Ethics 12 (3): 150-165.

Dworkin, G. 1988. The Theory and Practice of Autonomy. Cambridge: Cambridge University Press. 
Dwyer-Lindgren, L., et al. 2019. Mapping HIV Prevalence in SubSaharan. Nature 570: 189-193.

Eba, P.M. 2015. HIV-Specific Legislation in Sub-Saharan Africa: A Comprehensive Guman Rights Analysis. AHRLJ 15 (2): 224-262.

EGPAF. 2017. Communities Benefit from Door-to-Door HIV Testing [Online]. https://www.pedaids.org/2017/05/22/communitie s-benefit-from-door-to-door-hiv-testing. Accessed 19 May 2020.

Elster, J. 2016. Sour Grapes: Studies in the Subversion of Rationality. Cambridge: Cambridge University Press.

English, V., J. Mussell, A. Sommerville, and J. Sheather. 2006. Autonomy and Its Limits: What Place for the Public Good. In First Do No Harm: law, Ethics and Healthcare. Aldershot: Ashgate.

Faden, R.R., and T.L. Beauchamp. 1986. A History and Theory of Informed Consent. New York: Oxford University Press.

Feinberg, J. 1986. Harm to Self: The Moral Limits of Criminal Law, vol. 3. New York: Oxford University Press.

Frankfurt, H. 1988. The Importance of What We Care About. New York: Cambridge University Press.

Fraser, J. 2005. Ethics of HIV Testing in General Practice Without Informed Consent: A Case Series. Journal of Medical Ethics 31 (12): 698-702.

Friedman, M. 2003. Autonomy, Gender, Politics. New York: Oxford University Press.

Gaylin, W. 1996. Worshiping Autonomy. The Hastings Centre Report 26 (6): 43-45.

Gaylin, W., and B. Jennings. 2003. The Perversion of Autonomy: Coercion and Constraints in a Liberal Society. Washington, DC: Georgetown University Press.

Holton, R. 2003. Introduction to Philosophy: Free Will II [Online]. https://web.mit.edu/holton/www/edin/introfw/introfw2.pdf. Accessed 22 Mar 2020.

Huri-Laws v. Nigeria, Afr. Comm'n on Hum. \& Peoples' Rts., Communication No. 225/98, para. 40 (2000).

Hussain, W. 2018. The Common Good. The Stanford Encyclopedia of Philosophy [Online]. https://plato.stanford.edu/archives/spr2018/ entries/common-good/. Accessed 29 Apr 2020.

Jackson, E. 2013. Medical Law: Text, Cases and Materials, 3rd ed. New York: Oxford University Press.

Jones, T. 2020. After Coronavirus, The Penny has Dropped that Wellbeing isn't Individual but Social. The Guardian [Online]. https ://www.theguardian.com/world/2020/apr/12/after-coronaviru s-the-penny-has-dropped-that-wellbeing-isnt-individual-butsocial. Accessed 14 Apr 2020.

Kant, I. 1785. Groundwork of Metaphysic of Morals (H.J. Paton, Translated and Analysed). New York: Harper \& Row.

Kapitan, T. 2000. Autonomy and Manipulated Freedom. In Nous Supplement; Philosophical Perspectives, 14. Action and Freedom, ed. J. Tomberlin, vol. 34, 81-103. Oxford: Blackwell.

Kharsany, A.B.M., and Q.A. Karim. 2016. HIV Infection and AIDS in Sub-Saharan Africa: Current Status, Challenges and Opportunites. The Open AIDS Journal 10: 34-48.

Killmister, S. 2013. Autonomy and the Problem of Socialisation. Social Theory and Practice 39 (1): 95-119.

Konner, M. 1982. The Tangled Wing: Biological Constraints on the Human Spirit. New York: Holt, Rinehart \& Winston.

Lanier, M.M., and S. Henry. 2010. Essential Criminology, 3rd ed. Boulder: Westview Press.

Lewanika v. Frederick Chiluba (1998) Z.R. 79.

Mackenzie, C. 2008. Relational Autonomy, Normative Authority and Perfectionism. Journal of Social Philosophy 39 (4): 512-533.

Manson, N.C., and O. O'Neill. 2007. Rethinking Informed Consent in Bioethics. Cambridge: Cambridge University Press.

Mbiti, J.S. 1970. African Religions and Philosophy. New York: Doubleday Books.
McQuoid-Mason, D. 2008. An Introduction to Aspects of Health Law: Bioethical Principles. Human Rights and the Law. SAJBL 1 (1): 7-10.

Mele, A.R. 1995. Autonomous Agents: From Self-Control to Autonomy. New York: Oxford University Press.

Menkiti, I.A. 1984. Person and Community in African Traditional Thought. In African Philosophy: An Introduction, ed. R.A. Wright. Lanham: Maryland.

Mill, J.S. 2015. On Liberty, Utilitarianism, and Other Essays. Oxford: Oxford University Press.

Morison, R.S. 1984. The Biological Limits of Autonomy. The Heritage Centre Report 14 (5): 43-49.

Naidoo, S., and A. Vernillo. 2012. Ethical and Legal Issues on HIV Testing, Policy and the Practice of Dentistry. Journal of Forensic Odonto-Stomatology 30 (2): 7-16.

Nash, D., M. Yotebieng, and A.H. Sohn. 2018. Treating All People Living with HIV in Sub-Saharan Africa: A New Era Calling for NEW APPROACHES. Journal of Virus Eradication 4 (1): 1-4.

Ndete, A.D. 2016. Aristotelian Reconstruction of the Concept of Personal Identity. Sophia; An African Journal of Philosophy 17 (1): 134-148.

Nedelsky, J. 1989. Reconceiving Autonomy: Sources, Thoughts and Possibilities. Yale Journal of Law and Feminism 1 (1): 7-36.

Nussbaum, B. 2003. African Culture and Ubuntu: Reflections of a South African in America. World Business Academy 17 (1): $1-12$.

Ockham's Beard. 2010. Values and Moral Pragmatism [Online]. https://ockhamsbeard.wordpress.com/2010/07/22/values-andmoral-pragmatism/. Accessed 23 Apr 2020.

O'Neill, O. 2003. The Inaugural Address: Autonomy: The Emperor's New Clothes. Proceedings of the Aristotelian Society, Supplementary Volumes 77: 1-21.

Oppenheimer, G.M., and R. Bayer. 2009. The Rise and Fall of AIDS Exceptionalism. American Medical Association Journal of Ethics 11 (12): 988-992.

Oshana, M.A. 1998. Personal Autonomy and Society. Journal of Social Philosophy 29 (1): 81-102.

Planned Parenthood of SouthEastern PA. v. Casey. 1992. United States Supreme Court, 505 U.S. 833; 112 S.Ct. 2791; 120 L.Ed. 2d. 674.

Ravven, H.M. 2013. The Self Beyond Itself: An Alternative History of Ethics, the New Brain Sciences, and the Myth of Free Will. New York: The New Press.

Schermer, M. 2002. Autonomy in Medical Ethics: Issues of Informed Consent. In The Different Faces of Autonomy. Library of Ethics and Applied Philosophy, vol 13, 23-44. Dordrecht.

Selemogo, M. 2010. Evaluating the right to autonomy argument in the debate on coercive antenatal HIV testing in South Africa. SAJBL 3 (2): 63-66.

Silberner, J. 2019. They Thought This HIV Strategy Couldn't Work. But It Did [Online]. https://www.npr.org/sections/goatsandso da/2019/06/24/733674936/they-thought-this-hiv-strategycouldnt-work-but-it-did. Accessed 19 May 2020.

Skovdal, M. et al. 2016. Opportunities and challenges for 'test-andtreat': Insights from eastern and southern Africa [Online]. https://alpha.lshtm.ac.uk/files/2016/07/Connie-Opportunit ies-and-challenges-poster.pdf. Accessed 19 May 2020.

Smebye, K.L., M. Kirkevold, and K. Engedal. 2016. Ethical dilemmas concerning autonomy when persons with dementia wish to live at home: a qualitative, hermeneutic study. BMC Health Services Research 16 (21): 1-12.

Smith, J.H., and A. Whiteside. 2010. The history of AIDS exceptionalism. Journal of the International AIDS Society 13 (1): 1-8.

Song, J. 2018. Autonomy and Intervention in Medical Practice. Open Journal of Philosophy 8: 294-300. 
Southern Africa Litigation Centre. 2012. SALC Litigation Manual Series: Protecting Rights: Litigating Cases of HIV Testing and Confidentiality of Status. Johannesburg: SALC.

St Maarten AIDS Foundation. 2003. Testing: A Priority In AIDS Prevention [Online]. https://www.sxmaidsfoundation.org/test/ importance\%2520_of_testing.php\#.XsOM52gzaUk. Accessed 19 May 2020.

Stangl, A.L., and C.I. Grossman. 2013. Global Action to reduce HIV stigma and discrimination. Journal of the International AIDS Society 16 (2): 1-10.

Stoljar, N. 2000. Autonomy and the Feminist Intuition. In Relational Autonomy: Feminist Perspectives on Autonomy, Agency, and the Social Self, ed. C. Mackenzie and N. Stoljar, 94-111. Oxford: Oxford University Press.

Stoljar, N. 2014. Autonomy and Adaptive Preference Formation. In Autonomy, Oppression, and Gender, ed. A. Veltman and M. Piper, 227-255. New York: Oxford University Press.

Sulat, J.S., et al. 2018. The impacts of community-based HIV testing and counselling on testing uptake: A systematic review. Journal of Health Research 32 (2): 152-163.

Suthar, A.M., et al. 2013. Towards Universal Voluntary HIV Testing and Counselling: A Systematic Review and Meta-Analysis of community-Based Approaches. PLOS Medicine 10 (8): 1-23.

Taylor, R.S. 2005. Kantian Personal Autonomy. Political Theory 33 (5): 602-628.

Traphagan, J.W. 2013. Rethinking Autonomy: A Critique of Principlism in Biomedical Ethics. Albany: State University of New York.

Tutu, D. 1999. No Future Without Forgiveness. London: Rider.

Udjo, E.O., and P. Lalthapersad-Pillay. 2015. Assessing the Achievements of the Millenium Development Goals in Southern Africa. African Population Studies 29 (1): 1460-1471.

UN General Assembly. 2016. Resolution Adopted by the General Assembly on 8 June 2016: 70/266. Political Declaration on HIV and AIDS: On the Fast Track to Accelerating the Fight against HIV and to Ending the AIDS Epidemic by 2030, New York: United Nations.

UN News Centre. 2016. UN General Assembly Adopts Popitical Declaration to Fast-Track Progess on Ending AIDS [Online]. https ://www.un.org/apps/news/story.asp?NewsID=54172\#.WMKSm 8ZBrIU. Accessed 19 May 2020.

UNAIDS. 2014. Fast-Track: Ending the AIDS Epidemic by 2030. Geneva: UNAIDS.

UNAIDS. 2015. Understanding Fast-Track: Accelerating Action To End The AIDS Epidemic by 2030. Geneva: UNAIDS.
UNAIDS. 2016. Prevention Gap Report. Geneva: UNAIDS.

UNAIDS. 2020. 90-90-90: An Ambitious Treatment Target To Help End the AIDS Epidemic [Online]. https://www.unaids.org/en/ resources/909090. Accessed 19 May 2020.

UNAIDS. 2020a. Global HIV \& AIDS statistics-2019 fact sheet [Online]. https://www.unaids.org/en/resources/fact-sheet. Accessed 19 May 2020.

UNAIDS. 2020b. Test and Treat Showing Results in Uganda and Zambia [Online]. https://www.unaids.org/en/resources/presscentre/ featurestories/2018/april/test-and-treat-showing-results-in-ugand a-and-zambia. Accessed 19 May 2020.

UNAIDS. n.d. The benefits of knowing your HIV status [Online]. https ://www.unaids.org/sites/default/files/benefits-of-knowing-yourhiv-status_en.pdf. Accessed 19 May 2020.

United Nations. 2009. Report of the Special Rapporteur on the Right of Everyone to the Enjoyment of the Highest Attainable Standard of Physical and Mental Health-A/64/272. New York: United Nations.

United Nations. 2015. The Millennium Development Goals Report 2015. New York: United Nations.

United Nations. 2019. Transforming our World: The 2030 Agenda for Sustainable Development. United Nations Division for Social Policy and Development, Indigenous Peoples; 2017 [Online]. https://sustainabledevelopment.un.org/post2015/. Accessed 29 April 2020.

United Nations Department of Economic and Social Affairs (UNDESA). 2017. World Population Prospects: Key Findings \& Advance Tables 2017 Revision. New York: United Nations.

Velasquez, M., C. Andre, T. Shanks, and M.J. Meyer, 2014. The Common Good [Online]. https://www.scu.edu/ethics/ethics-resou rces/ethical-decision-making/the-common-good/. Accessed 29 April 2020.

Wenner, D.M. 2020. Non-Domination and the Limits of Relational Autonomy. IJFAB 13 (2): 98-119.

Westlund, A. 2009. Rethinking Relational Autonomy. Hypatia 24 (4): $26-49$.

Woods, J. M. 2002-2004. Rights as Slogans: A Theory of Human Rights Based on African Humanism. National Black Law Journal 17: 52-66.

Publisher's Note Springer Nature remains neutral with regard to jurisdictional claims in published maps and institutional affiliations. 